Paper received: October $10^{\text {th }} 2015$

Paper accepted: October $25^{\text {th }} 2015$

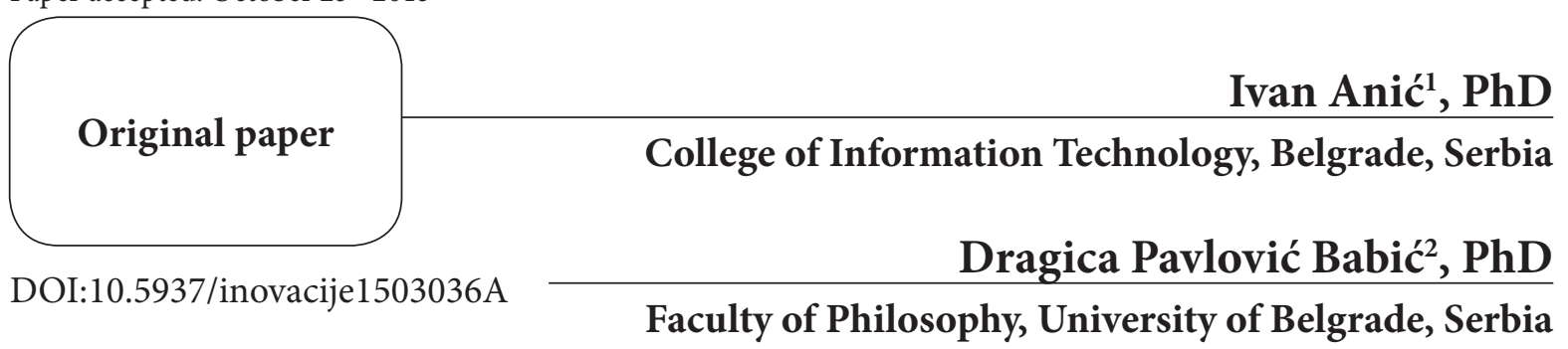

\title{
How we can support success in solving mathematical problems?
}

\begin{abstract}
The basic research question dealt with in this study is how to identify the main obstacles that students encounter in solving tasks in mathematics in order to define typical steps in mastering the mathematical skills needed for solving the applied tasks.

In conceptual terms, this study is situated into the contemporary definition of mathematical literacy as a competence that allows the individual to understand the world in which he/she lives, and makes him/her qualified to make informed decisions (e.g. OECD / PISA). This research had two phases. Study was divided into two phases, both of them included sample of first-grade high school students, which is consistent with the PISA criteria for determining sample. During students' individual or interactive work on tasks, their comments were collected as qualitative data in order to determine the ways in which students make mistakes, what are the difficulties encountered if the tasks are placed in a realistic context, and to determine which of these errors and problems are typical. Content analysis of students' verbal communication during task solving served to extract the problems that make solving strategies ineffective. In the second (quantitative) phase of our research, we tested if they could be used as a clear diagnosis that indicates a systemic deficiency in the teaching of mathematics and instruments for assessing student achievement. The sample consisted of 379 first grade students of Belgrade high schools. The results show that the concept of probability is intuitively close to the students' experience. Narrative rather than a graphical display of data is more efficient support in problem solving. Suggesting step-by-stepapproach to problem solving significantly increases performance. Recommendation for teaching practice is to introduce the concept of probability at earlier school ages and to integrate it with other themes in mathematics. Problem-solving strategies should be developed through active teaching of mathematics, in particular the skills of subdivision of a problem into stages.
\end{abstract} PISA).

Key words: mathematical literacy, problem solving, probability, strategies for solving tasks, OECD/

1 ianic@matf.bg.ac.rs

2 dpavlovi@f.bg.ac.rs 
Education in Serbia still lacks the established quality assurance system, whose function is, above all, to formulate further directions of development of education on the basis of evidences on quality, equity, and efficiency of the current educational practices. During the past decade this gap in the national evidences is to some extent compensated with the results of international assessment studies of student achievements in which Serbia was involved, such as programs of OECD/PISA and TIMSS. The findings of these research programs consistently show that the educational achievements of students from Serbia in terms of mathematical competence are below the international average. The gap in achievements compared to the $\mathrm{T}$ the international average is especially prominent when it comes to mathematical tasks that have the elements of the problem-situation that request application of mathematical knowledge in realistic situations (Baucal, Pavlovic Babic, 2011; Baucal, Pavlovic Babic, 2009; Baucal, 2006; OECD, 2004; OECD, 2007; OECD, 2010).

\section{Conceptual framework: the PISA study}

The research is based on materials and information on the achievements of students from Serbia within the framework of the International Programme for Student Assessment (PISA).

The PISA study systematically monitors the level of functional literacy in the field of mathematical, scientific and reading literacy the fifteen-yearold have attained in a given country. These three domains have been selected as the most general and the most relevant indicators of quality and equity of education (OECD, 2009a), as well as predictors of economic and social growth of society (OECD, 2009b).The specificity of the PISA study is that it does not examine the extent to which students can reproduce knowledge they have learned in school, but rather to what extent are they competent to understand and use available information and knowledge in solving relevant real-life problems. In ad- dition, the goal of the PISA study is to determine the extent to which different contextual factors (the characteristics of the education system, school characteristics, the characteristics of the family environment, and the characteristics of students) are related to the educational achievements of students (Rychen \& Salganik, 2003; OECD, 20054; Baucal \& Pavlovic Babic, 2009). OECD/PISA is arguably the most frequently referred international program in the field of education and one of the most important landmarks for educational policy. For example, literacy estimated according to the PISA test is one of the instruments that, at the EU level, is used for monitoring progression toward objectives of the EU Strategy 2020 (Eartl, 2006; European Commission, 2010).

\section{The concept of mathematical literacy}

Understanding the concept of mathematical literacy derived from the PISA study resulted with the following definition: Mathematical literacy assumes the individual's ability to recognize and understand the role that mathematics plays in the modern world, to make decisions based on facts and to use mathematics in order to conduct as constructive and research-oriented person able to assess himself/herself and the environment- (OECD, 1999). In short, the focus of such definition of mathematics, and therefore the role of the education system in the development of mathematical knowledge, is on the functional aspect of knowledge, that is on the use of knowledge.

Undoubtedly, in recent years a large number of countries (educational systems) have been devoted to examination and reorganization of their own curricula in mathematics, trying to solve the problem of "overemphasis on procedure and neglect of understanding" (de Lange, 2003), with clear orientations towards the integration of content. For example, in the mathematics curricula adopted in Poland, the program contents are organized by subjects, and at each level of education there is a list of compul- 
sory cross-curricular topics whose inclusion in the school curriculum is the responsibility of the school management/director (Polish Eurydice Unit, 2005). A similar solution was applied recently in Serbia by defining general and cross-curricular competencies for primary and secondary education. For Poland, we already know that applied reform measures positively affected the quality of education, which is visible, among other things, by the increase of the average achievement on the PISA tests. When it comes to Serbia, the question whether will introduced new competencies will find a way to become part of the everyday teaching practice still remains open.

Another high-achieving country in mathematics at the international testing is Singapore. Unlike academic approach to teaching mathematics which is typical in Serbia, curriculum in Singapore is problem-solving based. In Singapore, the central place of learning mathematics is the cooperative work on problem solving with a strong emphasis of metacognitive strategies (Ministry of Education, Singapore, 2013). In the textbooks, as well as in teaching, a large number of heuristics is in use (Fan \& Zhu, 2007).

In short, based on comparative analysis of legal and teaching program documents, we can estimate that the curricula of education systems which produce high mathematical achievement contain the explicit strategies for the support and development of higher order thinking (problem-solving, critical thinking), while in Serbia higher order thinking is not connected with specific content, but is only given as a general educational goal, with weak (if any) instructional power.

\section{The PISA achievements of students from Serbia}

During the four research cycles in which Serbia participated the average scores of Serbian students in 2003 were 437 points (on the scale with the arithmetic mean of 500, and standard deviation of 100), in 2006 it was the same one, in 2009 it was raised to 442 points, while in 2012 it was 445 (Pavlovic Babic, 2007; OECD, 2007; Baucal \& Pavlovic Babic, 2011; Pavlovic Babic,\& Baucal, 2013). Taking into consideration that one year of schooling has an average impact of 40 points on the PISA scale, it means that SerbianSerbian students are lagging behind for more than one school year compared to the international average.

Further analysis shows that the mathematics achievement of students from Serbia gradually increases in average 2 points per year. Although this is statistically significant, the advance rate is very small. With the trend of 2 points per year, Serbia should be about 25 years to reach the average achievement realized by students from OECD countries in 2012 (Pavlovic Babic, \& Baucal, 2013).

The average achievement has placed our students at the second level of the PISA achievement scale, which means that during the nine years of schooling, on average, students are trained to apply simple procedures, to find specific information using a single source for finding solutions in a simple situation in which all relevant information was provided. Requirements for that level require of students cognitive activity at the level of reproduction.

Findings from PISA 2012 cycle also show that the achievements of $38.9 \%$ of students from Serbia are below the level of functional literacy (OECD, 2013). At the same time, the achievements of just a small number of students (4.6\%) are at the two highest PISA math levels. This does not give an optimistic picture of the education system. Contrary, findings showed that the education is not oriented to compensate low achievement nor to encourage high ones.

All these findings suggest persuasively the need to improve the teaching of mathematics, particularly with regard to implementation of the acquired knowledge to problem situations in real life.

The main objective of the research study, similarly to our previous study (Anić \& Pavlović Babić, 2011), was to test the effectiveness of various ways of supporting students to solve complex mathemati- 
cal problems. Previous research studies conducted in Serbia show that the attention of researchers was much more focused on the factors that contribute to the achievement, such as motivation or school anxiety (Kovač Cerović i Radišić, 2015; Videnović i Radišić, 2011) or spontaneous strategies of students in problem solving (see, eg. Pavlović Babić, 2015). But, the researches dealing with the explicit strategies of problem solving are rare, at least when it comes to Serbia.

More specifically, the main aim was to identify the main obstacles encountered by students in solving these tasks, in order to, on this basis, formulate the typical steps in mastering the mathematical skills needed to solve the tasks situated in real context. Findings of this study can be useful from the perspective of improvement of teaching approaches.

\section{QUALITATIVE STUDY}

The aim. The aim of the qualitative part of the research is to identify different ways in which stu- dents make errors and to explore the difficulties they encounter in solving PISA tasks placed in a realistic context; finally, to identify which of these errors and difficulties are typical for Serbian students. The findings of this part of the study were used to construct new variants of the same PISA tasks were such difficulties are escaped.

\section{Method}

Description of the instrument and the research process. Students had to solve 6 tasks ( 4 taken from PISA, and 2 developed by the authors of the paper). The tasks were situated in a realistic life context and suited to the school age and experience of the respondents. Tasks tested different mathematical competences with graduated complexity. Due to limitations in the scope of this paper, we present only one of the tasks (Figure 1).

This is the original PISA task (Pavlovic Babic \& Baucal, 2009). It is a multiple choice question tied to everyday experience. All relevant informa-

Figure 1: The original version of the task 3

\section{COLOURED CANDIES}

Robert's mother lets him pick one candy from a bag. He can't see the candies. The number of candies of each colour in the bag is shown in the following graph.

What is the probability that Robert will pick a red candy?
A. $10 \%$
B. $20 \%$
C. $25 \%$
D. $50 \%$

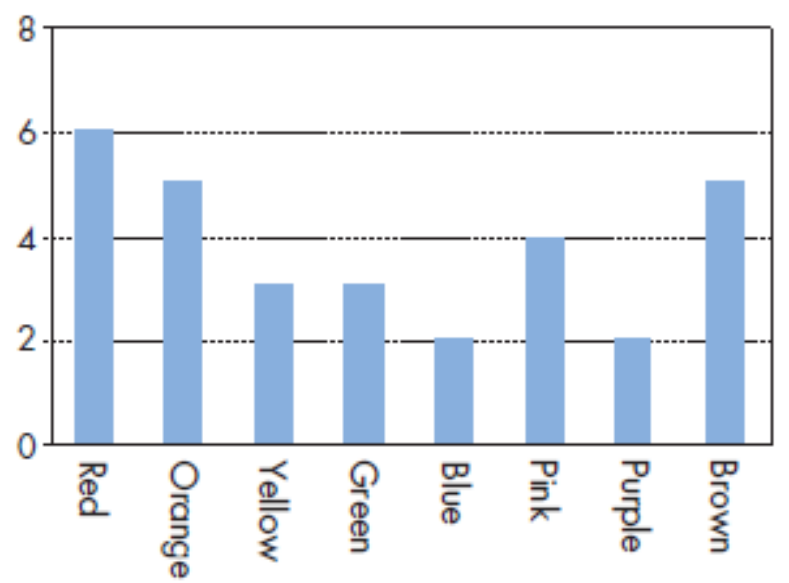


tion is given. The graph is simple and it is not essential for solving the task.

Students were expected to understand that the probability of drawing a red candy is equal to the percentage of red candies in the total number of candies in the bag.

In the curriculum for primary school, graphic data were not present until the school year 2009/10, so that students tested here were not used to this way of presentation of information in mathematics.

In Serbia, the concept of probability is not mastered before this level of education, so that students rely on implicit lay knowledge and analogies in solving these problems. The task is solved in several steps. Conceptual knowledge required for problemsolving and knowledge of procedures qualifies this task for the fourth achievement level (549 points on a scale of achievement). At the level of OECD countries 50\% of students solve this task (OECD, 2009c).

The sample. The sample includes 15 fifteen years olds students from upper secondary education, i.e. students attending the first grade of the upper secondary schools (this educational ages being tested in PISA).

In this part of the study 6 students from a Belgrade Gymnasium (2 working individually and 4 in pairs) and 9 students of a School of Economics in Belgrade ( 3 individuals and 6 working in pairs). Students were selected based on two criteria in consultation with the math teacher: (a) ability to reflect and express their thinking aloud, and (b) school marks in mathematics. Considering that the aim of this phase was the determination of different problem-solving strategy, the highly expressive students with high achievement in mathematics were chosen.

\section{Results}

The content analysis was applied on data collected during the qualitative part of the study. Unlike other qualitative techniques, dialogic problem solving proved to be particularly suitable for the purposes of this study (Snape \& Spencer, 2003), because it is made possible insight into the strategies that students apply. The analysis can take only those parts of dialogues. The analysis can take only those parts of the dialogue which were explicitly referred to the way of solving problems. Other parts of the dialogue, including non-verbal communication, are ignored.

Content analysis of verbal communication during solving all included PISA tasks revealed the following problems, which make the solving strategies ineffective:

1. Choice of the relevant data. It turned out that the students had false expectations that all information given must be used in order to come up with a solution. This false belief leads to erroneous attempts to solve, and illogical results lead them back to the beginning. All students were able to overcome the difficulties, and the process lasted from 30 seconds to 3 minutes.

2. Reading the information presented in the picture. The picture obstructs the process of solving the tasks in the following ways:

- Wrong interpretation of the picture - for instance, a schematic representation of the staircase (the first task) misled students to apply the Pythagorean Theorem.

- Visually striking difference in the height of columns on the chart led to a quick, laconic answer that difference is great because it is clearly so in the picture.

- Checking and comparing the information given in the picture and in the text. This strategy is not wrong, but it is redundant and slows down the solving process.

3. Relating the different phases during the problem solving. All students who participated in this part of the research, except one pair, tried to respond directly to the 
assignment, on the basis of the given information, without any attempt to analyze and reflect.

4. Presentation of information by spatial distribution of objects, or a scheme or on the mental plane.

Based on the identified problems, we have intervened in tasks (re-designed them) so to avoid typical mistakes, or to help students move on to the next phase of problem solving. For each math problem, two additional variants were defined: Variant B, in which the task is made easier removing barriers in solving, and variant $\mathrm{C}$, which is further facilitated by being made the first step that leads to a solution.

\section{QUANTITATIVE STUDY}

The specific objective of the quantitative phase of the research presented in this paper was to whether errors and difficulties registered in the previous phase are typical for Serbian students. Being typical, they clearly identify and indicate a systemic issues in the teaching of mathematics as well as potential validity issues related to the PISA math tasks using for assessing math achievement of Serbian students.

\section{Method}

\section{Instruments}

The research was designed so that, by intervening in the nature of the tasks, we eliminate or reduce the possibility of error and thereby increase efficiency in solving problems. On the basis of errors in problem solving, noted during the qualitative study, tasks are modified in one of the following ways: remove redundant information, remove the image when the information are given in narrative, divide the instruction into clearly defined steps of solving process, and explicitly pointed out the nature of the data.
Prior, explicit division of instruction in stages (steps) results in increased success in solving the tasks. Statistically, we expect students to be more successful in solving $\mathrm{B}$ and $\mathrm{C}$ variants of the original tasks.

\section{Variables}

Dependent variable:

- Mathematical achievement in solving of problems expressed by the accuracy of solving particular tasks in the test.

Independent variables:

- Assessment of mathematics, as a measure of student's school achievement;

- The number of points in the admission exam at the end of the eighth grade.

Control variable:

- Age of respondents. All the participants in this study were of the same age of the formal education (the first year of secondary school).

\section{Hypotheses}

Here is the list of all hypotheses tested in the research. In discussion, we focus on hypotheses 3, 4 and 7 , which are related to the presented task 3 .

1. Elimination of redundant data in the first task increases the effectiveness in solving problems. Removing the image in the same task, as redundant, increases success in solving tasks.

2. Pointing to the nature of the data in the second task increases the effectiveness in solving tasks. Direct instruction to use of the same data additionally increases performance.

3. Definition of phases of the problem solving increases effectiveness in solving tasks.

4. Removing image, when the data are already contained in narrative, increases effectiveness in solving problems. 
5. Referring to the position of the objects on the plane increases the success.

6. The first graders (high school) do not have competence to apply the reverse Pythagorean Theorem in a real context. We expect that, regardless of the fact that students meet with numerous tasks using the Pythagorean Theorem, the number of students who are able to exactly solve the task is very small.

7. School success, presented as scores in mathematics at the end of eighth grade and the results of the qualifying exam in mathematics, is a predictor of the achievement on the math test. We expect that students who are successful in solving math problems within a real life context will have significantly better scores of school success (scores in mathematics achievement in the

Figure 2: Variant B of the third task admission exam) than the students who fail to solve these tasks.

\section{Instrument}

Based on the findings from the qualitative part of the study we conceived for each task two variants - variant $\mathrm{B}$ and variant $\mathrm{C}$ in which the identified difficulties and errors were escaped. For example, variant B of the task 3 is worded so that suggests the division of tasks in phases. In this variant, the assistance was not given either as explanation of the concept of probability or as a suggested procedure for solving a task.

In version $\mathrm{C}$ of the third task (Figure 3 ) the data are supplied narratively rather than as a graph. In addition, the word probability is replaced with the word chance that, in our view, is closer to the students' experience.

Figure 2 and 3 shows a modified variant of the task $3^{\text {rd. }}$

\section{COLOURED CANDIES}

Robert's mother lets him pick one candy from a bag. He can't see the candies. The number of candies of each colour in the bag is shown in the following graph.

Fill the table with numbers

of candies of each colour.

Red Orange Yellow Green Blue

Pink Purple Brown Total

What is the probability that Robert will pick a red candy?
A. $10 \%$
B. $20 \%$
C. $25 \%$
D. $50 \%$

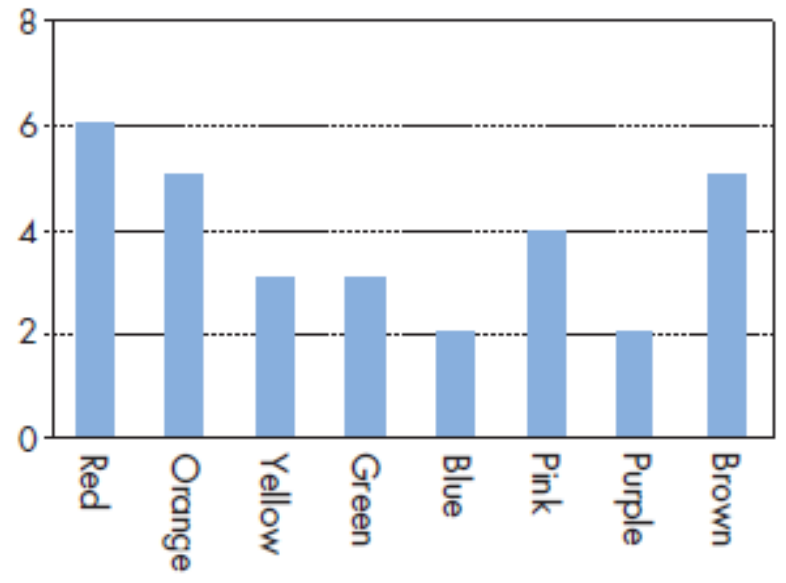




\section{COLOURED CANDIES}

Robert's mother lets him pick one candy from a bag. He can't see the candies. The bag contains 6 red, 5 orange, 3 yellow, 3 green, 2 blue, 4 pink, 2 purple, and 5 brown candies.

What is the chance that Robert will pick a red candy?
A. $10 \%$
B. $20 \%$
C. $25 \%$
D. $50 \%$

There were three versions of the test, each comprising the 6 tasks: two tasks of variant $\mathrm{A}$, two tasks of variant $B$, and two tasks of variant $C$, so that each of the tested students took two tasks of each variant. In this way the load was spread evenly and the decrease of motivation for difficult tasks was avoided. Table 1 presents the structure of all versions of the test.

Table 1. Test structure

\begin{tabular}{|l|c|c|c|c|c|c|}
\hline & $\begin{array}{c}\text { First } \\
\text { task }\end{array}$ & $\begin{array}{c}\text { Second } \\
\text { task }\end{array}$ & $\begin{array}{c}\text { Third } \\
\text { task }\end{array}$ & $\begin{array}{c}\text { Fourth } \\
\text { task }\end{array}$ & $\begin{array}{c}\text { Fifth } \\
\text { task }\end{array}$ & $\begin{array}{c}\text { Sixth } \\
\text { task }\end{array}$ \\
\hline $\begin{array}{l}\text { First } \\
\text { version }\end{array}$ & A & B & C & C & B & A \\
\hline $\begin{array}{l}\text { Second } \\
\text { version }\end{array}$ & C & A & B & B & A & C \\
\hline $\begin{array}{l}\text { Third } \\
\text { version }\end{array}$ & B & C & A & A & C & B \\
\hline
\end{tabular}

Table 2. Sample structure and data on school performance

\begin{tabular}{|l|c|c|c|c|c|c|c|}
\hline & School 1 & School 2 & School 3 & School 4 & Total & $\begin{array}{c}\text { Entrance } \\
\text { Exam Score }\end{array}$ & $\begin{array}{c}\text { Average } \\
\text { School Mark }\end{array}$ \\
\hline Version A & 30 & 30 & 42 & 22 & 124 & 15.51 & 4.11 \\
\hline Version B & 27 & 29 & 40 & 33 & 129 & 15.50 & 4.24 \\
\hline Version C & 29 & 26 & 41 & 30 & 126 & 15.66 & 4.15 \\
\hline Total & 86 & 85 & 123 & 85 & 379 & & \\
\hline
\end{tabular}




\section{Data processing plan}

The data were processed in the SPSS statistical package. We applied the descriptive statistical analysis (significance of differences of arithmetic means).

\section{Findings}

Table 3 shows the frequency response of students.

Table 3. Response distribution according various variants of the third task

\begin{tabular}{|l|c|c|c|c|}
\hline & $\begin{array}{c}\text { Correct } \\
\text { Answer }\end{array}$ & $\begin{array}{c}\text { Correctly } \\
\text { Filled Table } \\
\text { (B) }\end{array}$ & $\begin{array}{c}\text { Wrong } \\
\text { Answer }\end{array}$ & $\begin{array}{c}\text { Did not } \\
\text { work }\end{array}$ \\
\hline Variant A & $36.51 \%$ & & $61.90 \%$ & $1.59 \%$ \\
\hline Variant B & $46.51 \%$ & $96.90 \%$ & $53.49 \%$ & $0.00 \%$ \\
\hline Variant C & $54.03 \%$ & & $44.35 \%$ & $1.61 \%$ \\
\hline
\end{tabular}

The data show that between the students who solved modified variants of the task and the students who have worked with the original version, there are significant differences in achievements. We used the t-test for equality of proportions in the three variants of the task (every two variants were compared); these findings are presented in Table 4.

Table 4. Testing equality of proportions with various variants of the third task

\begin{tabular}{|l|c|c|c|}
\hline & A-B & A-C & B-C \\
\hline $\begin{array}{l}\text { Expected } \\
\text { difference }\end{array}$ & $-10.00 \%$ & $-17.52 \%$ & $-7.52 \%$ \\
\hline p-value & $0.053^{\star}$ & $0.003^{\star *}$ & 0.117 \\
\hline
\end{tabular}

Analysis of the data indicates the following:

1. Practically, all students know to read data from the chart. Although in school prac- tice such representation of data is not used, graphic representation of the data is understandable to students, probably as part of their everyday experience (this kind of presentation is often used by electronic and printed media).

2. Pointing to the first step significantly helps in solving the task (the difference between variants $A$ and $B$ ). It was enough just to point to the division of the solving process into stages, and students would significantly better do the job. This confirms the third hypothesis of this study.

3. Statistical analysis showed that between students who worked on variant $B$ and those who worked on variant $\mathrm{C}$ there is no significant difference in achievement. Therefore, the analysis of the data does not support the fourth hypothesis.

4. We have analysed the extent to which school achievement in mathematics predicts the performance on a task 3 . The results are shown in Table 5. They indicate that the seventh hypothesis is confirmed only for the modified variants of task, and only in the case of school success as measured by scores in mathematics in the 8th grade. In task variant $A$ data do not indicate the existence of any positive correlation between success on the tasks and school success, i.e. better academic achievement in no way guarantees better achievements in the test. 
Table 5. Testing difference averages in school success and wrong solution of the third task

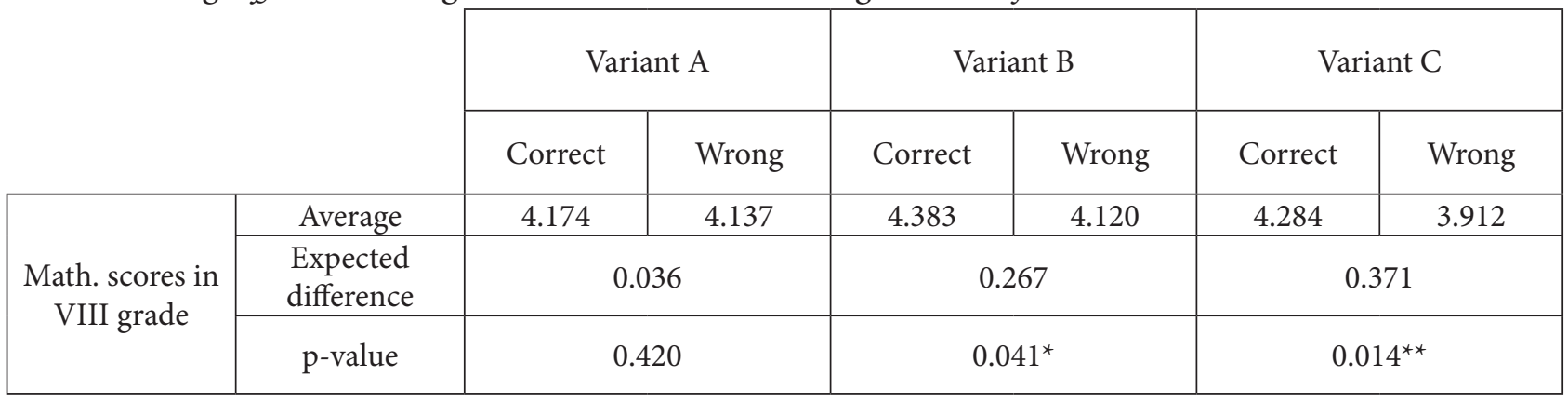

5. There is a big difference in achievements between variants $A$ and $C$. In variant $C$, the task was fully translated into narrative and the word "probability" was replaced by the term "chance", which is used in everyday communication. Obviously, there were two interventions in this task, but both in the same spirit. Since the result for variant B shows that the students were able in almost hundred per cent to read the chart, we can assume that the replacement of terms (chance instead of probability) had greater influence on the difference in achievements. The overall conclusion would be that closer the task is to everyday language and experience of students (e.g. lower level of abstraction, less symbolic representation, informal language...), better gets the students' involvement in problem solving. This leads us to the conclusion that the difference in achievement does not depend on mathematical knowledge, but on the ability to translate the real situation into the language of mathematics; very likely, the same effect happens with the direct motivation for solving the task, which was increased by placing the task in the known context.

\section{Discussion and Conclusion}

The qualitative part of the research shows that most students understand the concept of probability, although they did not encounter with this notion at school; they translate it as "chance" or "likelihood". This notion is so natural that some students were not even aware of the fact that it was not a part of the school teaching.

The results of the quantitative part of the study show that students have more difficulties with segmentation of the solution process into the stages than with the concept of probability. It is clear that in a naive form this concept should be introduced much earlier in school curriculum, mostly due to the great importance that the probability and statistics play in contemporary society. Today, the concepts of statistical probability are a part of general education; it goes without saying that the admission tests for almost all jobs contain problems of that kind. The absence of probability and statistics from teaching mathematics in Serbia is systemic; it would be much better if teaching mathematics incorporates these concepts soon and in the early grades of elementary school. Problems of probability and statistics are by their nature realistic and can greatly inspire students. In addition, knowledge of basic statistical concepts expands students' opportunities for research, not only in mathematics, but also in other areas. 
In accordance with the best educational practices in the world, teaching of mathematics in Serbia should be a problem and project oriented. In this way, we could achieve greater involvement of students in teaching/learning process and develop problem-solving strategies needed for the further education, as well as for functioning in daily life. It is also the basis for developing higher order thinking including critical thinking.

Initial teacher education in Serbia, as it is today, is more focused on building mathematical knowledge and less on the development of teacher competencies. This is why we recommend that the initial education and professional training of teachers include, in greater extent, the development of teaching skills, aimed at organizing problem solving and project-oriented teaching.

Even with unchanged initial teacher education and unchanged mathematics curricula in schools in Serbia, we believe that it is possible to make changes at the classroom level. Even very strict curricula still leave the place for teachers to bring a problemsolving and project component in the teaching of mathematics. In that way, students would be more engaged during the class, teaching would be more interesting, and achievements would increase.

\section{References}

- Anić, I. \& Pavlović Babić, D. (2011). Rešavanje matematičkih problema u realnom kontekstu: kvalitativna i kvantitativna analiza postignuća. Nastava i vaspitanje, 2, 193-205.

- Baucal, A. \& Pavlović Babić, D. (2009). Kvalitet i pravednost obrazovanja u Srbiji: Obrazovne šanse siromašnih. Belgrade: Ministarstvo prosvete Republike Srbije, Vlada Republike Srbije, Institut za psihologiju.

- Baucal, A. \& Pavlović Babić, D. (2011). Nauči me da učim, nauči me da mislim, PISA 2009 u Srbiji: prvi rezultati, Belgrade: Institut za psihologiju i Centar za primenjenu psihologiju.

- Baucal, A. i sar. (2006). Obrazovna postignuća učenika III razreda - nacionalno testiranje 2004, Beograd: Zavod za vrednovanje kvaliteta obrazovanja i vaspitanja. http://www.ceo.edu.rs/images/stories/publikacije/ ObrazovnaPostignucaUcenika.pdf

- Eartl, H. (2006):. European Union policies in education and training: the Lisbon agenda as a turning point? Comparative Education, 42 (1,) 5-27.

- European Commission (2010): Europe 2020: A European strategy for smart, sustainable and inclusive growth. Brussels: European Commission.

- Fan, L., \& Zhu, Y. (2007). Representation of problem-solving procedures: A comparative look at China, Singapore, and US mathematics textbooks. Educational Studies in Mathematics, 66(1), 61-75.

- de Lange, J. (2003). Mathematics for Literacy. In B. L. Madison, \& L. A. Steen (Eds). Quantitative Literacy: Why Literacy Matters for Schools and Colleges, Princeton, New Jersey: National Council on Education and the Disciplines. 75-89.

- Kovač Cerović, T. \& Radišić, J. (2015):.Sprega motivacije i postignuća učenika: doprinos PISA 2009. In J. Radišić, \& N. Buđevac, (Eds.), Sekundarne analize istraživačkih nalaza u svetlu novih politika u obrazovanju Belgrade: Ministarstvo prosvete, nauke i tehnološkog razvoja Republike Srbije i Društvo istraživača u obrazovanju. 144-158

- Ministry of Education, Singapore (2013). Primary Mathematics Teaching and Learning Syllabus, http://www.moe.gov.sg/education/syllabuses/sciences/files/maths-primary-2013.pdf) 
- OECD (1999). Measuring Student Knowledge and Skills: A New Framework for Assessment. Paris: OECD Publications.

- OECD (2004). Learning for Tomorrow's World: First Results from PISA 2003. Paris: OECD Publications.

- OECD (2007). PISA 2006: Science competencies for tomorrow's world. Paris: OECD Publications.

- OECD (2009a). Education at a Glance. Paris: OECD Publications.

- OECD (2009b). Education Today: The OECD Perspective. Paris: OECD Publications.

- OECD (2009c). PISA 2009 Results: What Students Know and Can Do. Volume I, Paris: OECD Publications.

- OECD (2013). PISA 2012 Results: What Students Know and Can Do - Student Performance in Mathematics, Reading and Science (Vol. 1), Paris: OECD Publications.

- Pavlović Babić, D. (2015). Faktori koji doprinose postignućima na PISA zadacima čitalačke pismenosti. In J. Radišić \& N. Budjevac (Eds.), Sekundarne analize istraživačkih nalaza u svetlu novih politika u obrazovanju. Belgrade: Ministarstvo prosvete, nauke i tehnološkog razvoja Republike Srbije i Društvo istraživača u obrazovanju. str. 118-121.

- Pavlović Babić, D. \& Baucal, A. (2009). Matematička pismenost. Belgrade: Ministarstvo prosvete Republike Srbije, Zavod za vrednovanje kvaliteta obrazovanja i vaspitanja, Institut za psihologiju Filozofskog fakulteta Univerziteta u Beogradu.

- Pavlović Babić, D., \& Baucal, A. (2013). Podrži me, inspiriši me: Prvi rezultati PISA 2012 u Srbiji, Beograd: institut.leI za psihologiju i Centar za primenjenu psihologiju.

- Polish Eurydice Unit (2005). The System of Education in Poland. Warsaw: Foundation for Development of the Education System.

- Rychen, D. S. \&. Salganik, L. H. (Eds.) (2003). Key Competencies for A Successful Life and a Well-Functioning Society. Cambridge: Hogrefe \& Huber Publishers.

- Snape, D. \& Spencer, L. (2003). The foundations of qualitative research. In: Richie, J. \& Lewis, J. (Eds.). Qualitative research practice. A guide for social science students and researchers, London: SAGE Publications. 2-23.

- Videnović, M. \& Radišić, J. (2011). Anksioznost u vezi sa učenjem matematike: Matematika - bauk ili ne? Psihološka istraživanja, 14, 157-177. 


\section{др Иван Анић}

Висока школа за информационе технологије, Београд, Србија

\section{др Драгица Павловић Бабић}

Филозофски факултет, Универзитет у Београду, Србија

\section{Како се може поспешити успешност ученика у решавању математичких проблема?}

Основно истраживачко питање којим се бавимо у овом раду је питање идентификовања погрешних стратегија и основних препрека у решавању проблемских задатака из математике, како би се дефинисале успешне подршке у процесу решавања, а које доводе до успеха.

Истраживање је реализовано у две фазе. Квалитативним истраживањем, у условима индивидуалног рада или рада у пару на задатку, настојали смо да утврдимо на које начине ученици греше и на које потешкоће наилазе при решавању задатака смештених у реалан контекст, као и да се утврди које од тих грешака и потешкоћа су типичне. Анализом садржаја вербалних исказа ученика током решавања задатака издвојени су проблеми који чине стратегије решавања неефикасним.

Квантитативним истраживањем проверавали смо у којој мери су грешке и потешкоће установљене у претходној фази типичне, што може бити јасан дијагностички знак који указује на системски недостатак у настави математике и инструментима за процену постигнућа ученика.

Узорак ученика обухвата петнаестогодишњаке, односно ученике првог разреда из четири средње школе у Београду. У квалитативном делу истраживања учествовало је петнаест ученика, а у квантитативном триста седамдесет и девет ученика. Узорак школа је пригодан, а у свакој школи су тестирана цела одељења која су насумично изабрана.

Узорак задатака чини шест проблемских математичких задатака, од којих су четири преузета из међународног програма провере ученичких постигнућа (ОЕЦД/ПИСА), а два су саставили аутори овог рада. Задаци су смештени у реалан контекст и у складу су са узрастом и искуствима испитаника. Задаци тестирају различите математичке компетенције и градуирани су по комплексности.

Анализом садржаја вербалних исказа ученика током решавања задатака издвојили су се следећи проблеми који чине стратегије решавања неефикасним: (1) Избор релевантних података - показало се да су ученици имали погрешна очекивања да сви дати подаци морају да се употребе да би се дошло до решења; (2) Читање сликом датих података - слика је ометала процес решавања задатака на следеће начине: погрешно интерпретирање слике, погрешно интерпретирање због нејасноће у графичком приказу података, проверавање и упоређивање података који су дати сликом и текстом, што доводи до успоравања процеса решавања задатка; (3) Повезивање различитих фаза у решавању задатка - показало се да ученици покушавају да директно дођу до решења без претходне анализе расположивих података; (4) Представљање, схемом или на менталном плану, података о просторном распореду објеката.

На основу уочених проблема, интервенисали смо у задацима тако да се избегну типичне грешке или помогне ученицима у преласку на наредне фазе решавања проблема. За сваки задатак формулисане су две олакшане верзије: Б верзија, у којој је дат директнији приказ података, и Ц верзија, у којој се ученици наводе на први корак у решавању задатка. 
За потребе овог рада приказане су анализе које се односе на проблемски задатак из области вероватноће у којем су подаци дати графиком.

У квалитативном делу истраживања се показало да већина ученика зна за појам вероватноће, иако се са тим појмом нису сусрели у школи, и преводе га појмовима „шанса“ или „могућност“. Тај појам је толико природан ученицима да неки нису ни знали да у школи нису учили ништа о вероватноћи.

Резултати квантитативног дела истраживања показују да је већи проблем ученицима да поделе проблем у фазе него сам концепт вероватноће. Јасно је да овај концепт треба на један наиван начин много раније изучавати у школи, а највише због великог значаја који вероватноћа и статистика играју у савременом друштву. Статистичко-вероватносни концепти се данас убрајају у општеобразовне, и скоро да нема послова где се за пријем не раде тестови који садрже проблеме из ове области. Проблем мањка вероватноће и статистике у настави математике у Србији је системски и биће боље за наставу математике ако се ови концепти ускоро нађу у нижим разредима основне школе. Проблеми из вероватноће и статистике су по својој природи реалистични и могу у великој мери инспирисати ученике. Осим тога, познавање основних статистичких концепата проширује ученицима могућности за истраживачки рад, не само из предмета математика већ и у другим областима.

Налази истраживања могли би да имају импликације и на системска решења која се примењују у образовању, али и на свакодневну наставну праксу. Иновирање програма иницијалног образовања наставника математике, као и програма курикулума за основне и средње школе, требало би да иде у правцу подржавања наставничких компетенција за проблемску и пројектно организовану наставу којом би се подржали виши облици мишљења код ученика. У очекивању промена на системском нивоу могуће је унапредити и свакодневни рад у учионици тако што би се кроз проблемске задатке и кооперативни рад ученика на њима постигао виши степен ангажовања ученика у настави, подигао квалитет наставе и унапредила образовна постигнућа ученика у области математике.

Кључне речи: математичка писменост, решавање проблема, вероватноћа, стратегије решавања задатака, програм ПИСА. 